\title{
Proapoptotic BID is required for myeloid homeostasis and tumor suppression
}

\author{
Sandra S. Zinkel, ${ }^{1}$ Christy C. Ong, ${ }^{1}$ David O. Ferguson, ${ }^{2}$ Hiromi Iwasaki, ${ }^{3}$ Koichi Akashi, ${ }^{3}$ \\ Roderick T. Bronson, ${ }^{3}$ Jeffery L. Kutok, ${ }^{3}$ Frederick W. Alt, ${ }^{2}$ and Stanley J. Korsmeyer ${ }^{1,4}$ \\ ${ }^{1}$ Howard Hughes Medical Institute, Departments of Pathology and Medicine, Harvard Medical School, Dana-Farber Cancer \\ Institute, Boston, Massachusetts 02115, USA; ${ }^{2}$ Howard Hughes Medical Institute, Division of Immunology, Boston \\ Children's Hospital, Center for Blood Research, Department of Genetics, Harvard Medical School, Boston, Massachusetts \\ 02115, USA; ${ }^{3}$ Department of Pathology, Harvard Medical School, Boston, Massachusetts 02115, USA
}

The proper expansion and contraction of hematopoietic cells requires tight regulation of cell death. BID, a "BH3-only" molecule, amplifies death receptor signals connecting the extrinsic to intrinsic pathways by triggering the mitochondrial pathway of apoptosis. Bid-deficient mice, as they age, spontaneously develop a myeloproliferative disorder, which progresses from myeloid hyperplasia to a fatal, clonal malignancy closely resembling chronic myelomonocytic leukemia (CMML). Thus, an apoptotic defect can result in myeloid leukemogenesis. Premalignant Bid-/- myeloid precursor cells are resistant to death receptor-induced apoptosis. Furthermore, a competitive reconstitution assay demonstrates that Bid-deficient long-term repopulating cells give rise to expanded myelomonocytic cells in vivo. Surprisingly, a single BH3-only molecule operating in the extrinsic death receptor pathway proved essential in vivo for physiologic cell death required to maintain myeloid homeostasis. Moreover, progression to CMML indicates that an upstream BH3-only molecule, BID, is required to suppress tumorigenesis.

[Keywords: BID; BCL-2; myeloid; cancer; apoptosis; Fas]

Received September 27, 2002; revised version accepted November 15, 2002.

Multicellular organisms have developed a highly organized and carefully regulated pathway of cell suicide to control homeostasis and ensure survival of the organism as a whole. Normal development and morphogenesis proceeds by the production of excess cells which are then removed by a genetically programmed, evolutionarily conserved process. This same program of cell death is used to maintain homeostasis of cell populations in long-lived mammals and to respond to both physiologic and pathologic death stimuli such as infectious agents.

The BCL-2 family of proteins controls a critical decisional checkpoint in the cell death pathway operating immediately upstream of mitochondria (Adams and Cory 1998; Gross et al. 1999a). Pro- as well as antiapoptotic members have been identified. The proapoptotic members can be further subdivided into "multidomain" members, such as BAX and BAK, harboring four BCL-2 homology domains (BH1-4), and "BH3-only" members such as BID, BAD, BIM, BIK, NOXA, HRK, and PUMA. Cells doubly deficient in Bax and Bak are profoundly resistant to multiple apoptotic stimuli that signal through the intrinsic pathway, indicating that multidomain BAX, BAK are essential downstream death effec-

${ }^{4}$ Corresponding author.

E-MAIL stanley_korsmeyer@dfci.harvard.edu; FAX (617) 632-6401.

Article and publication are at http://www.genesdev.org/cgi/doi/10.1101/ gad.1045603. tors required for the mitochondrial pathway of apoptosis (Wei et al. 2001). In contrast, BH3-only molecules appear to operate upstream, connecting proximal death signals to the "multidomain" antiapoptotic and proapoptotic BCL-2 members at the mitochondria (Cheng et al. 2001; Zong et al. 2001). BID was the first identified member of the BH3-only subset and is capable of binding multidomain proapoptotic BAX, BAK as well as antiapoptotic BCL-2 (Wang et al. 1996). BID appears unique among the BH3-only members as it interconnects the extrinsic pathway initiated by death receptors to the intrinsic pathway of mitochondria-based cell death. Following death receptor signaling, caspase- 8 is activated, which cleaves the inactive p22 conformer within an unstructured loop (Li et al. 1998; Luo et al. 1998; Gross et al. 1999b), which exposes a glycine that is N-myristoylated (Zha et al. 2000). This p 7/myr-p15 BID complex targets mitochondria with increased efficiency to trigger cell death. BID establishes a proapoptotic cascade where the BH3 domain of BID induces BAX, BAK to undergo an allosteric activation, including their homo-oligomerization at the mitochondrion, resulting in permeabilization of the outer membrane and the release of cytochrome $c$ (Wei et al. 2000). In cells protected by adequate amounts of BCL-2, BCL- $\mathrm{X}_{\mathrm{L}}$ activated BH3-only molecules including tBID are sequestered by these antiapoptotic members, preventing the activation of BAX, BAK (Cheng et al. 2001). 
In contrast to the pervasive defect in apoptosis displayed by BAX, BAK doubly deficient cells, Bid-deficient cells display a very focused deficit following death receptor activation. Bid-deficient mice are viable and develop normally, and at birth display balanced homeostasis in all examined tissues. However, when challenged with pathologic Fas activation in vivo, Bid-deficient livers proved resistant to Fas-mediated hepatic apoptosis and hemorrhagic necrosis that kills wild-type mice (Yin et al. 1999). Moreover, other BH3-only molecules also function as upstream connectors that participate in a signalspecific and lineage-restricted fashion. BAD is activated and inactivated through its differential phosphorylation in response to extracellular survival factors (Zha et al. 1996). PUMA and NOXA are induced by p53 in response to DNA damage (Nakano and Vousden 2001). BIM associates with a dynein light chain, suggesting that it could prove to monitor aberrations of this microtubule complex (Puthalakath et al. 1999). Bim-deficient mice demonstrate persistence of autoreactive thymocytes and plasma cell expansions (Bouillet et al. 1999, 2002). The focused roles of each BH3-only molecule and the selective defects in cells deficient for a BH3-only molecule contrast with the global defect in $B A X, B A K$ doubly deficient cells, suggesting a model in which $\mathrm{BH} 3$-only molecules often work in concert. $\mathrm{BH} 3$ domain peptides were recently subdivided into "activators" and "sensitizers" and were shown to be synergistic in inducing apoptosis (Letai et al. 2002).

Thus, a considerable question exists as to whether any single BH3-only protein, and especially BID, which functions as an upstream amplifier in the death receptor pathways, would be essential to control homeostasis of a cell lineage in vivo. BCL-2 was discovered at the $t(14 ; 18)$ chromosomal breakpoint of human follicular lymphoma. Transgenic mice bearing a BCL-2-Ig minigene that recapitulated this breakpoint developed B-cell follicular hyperplasia that progressed to monoclonal, large cell lymphoma (McDonnell et al. 1989; McDonnell and Korsmeyer 1991). BCL-2 functions by extending cell survival and conferring resistance to apoptosis, which initiated a new category of oncogenes: regulators of cell death (Vaux et al. 1988; McDonnell et al. 1989; Hockenbery et al. 1990). Similarly, proapoptotic BCL-2 members might be expected to serve as tumor suppressors and their loss-of-function to contribute to malignancy. Choroid plexus tumors were accelerated by introducing $B a x$ deficiency together with a truncated SV40 $\mathrm{T}$ antigen transgene (Yin et al. 1997). However, singly deficient Bax or Bak null mice have not developed a high incidence of spontaneous tumors (Knudson et al. 1995; Lindsten et al. 2000). Adding an adenoviral E1A oncogene to the profound apoptotic block of Bax, Bak doubly deficient cells is sufficient to transform them (Degenhardt et al. 2002). However, surviving mice doubly deficient for Bax, Bak have not to date spontaneously developed tumors (Lindsten et al. 2000).

Here we extensively examined Bid-deficient mice and discovered that the myelomonocyte lineage is singularly dependent on BID for physiologic cell death. Bid-deficient bone marrow initially displays increased clonogenic potential in vitro and enhanced regenerative potential in competitive repopulation assays. Over time, Bid null mice display a myeloid hyperplasia which progresses to a fatal clonal disorder resembling human chronic myelomonocytic leukemia (CMML). Thus, BID, a single BH3-only molecule, plays an essential role in maintenance of myeloid homeostasis and tumor suppression.

\section{Results}

Bid-deficient mice display altered myeloid homeostasis

Analysis of aging Bid-deficient mice revealed an elevated absolute neutrophil count at age 18-24 mo accompanied by mild hepatosplenomegaly due to infiltration of myeloid cells (Table 1). Hematopoietic cell populations in younger Bid-/- mice (<12 mo old) were indistinguishable from age- and sex-matched wild-type controls. This prompted a detailed analysis of bone marrow in which young (6-12-wk-old) Bid-deficient mice demonstrated increased colony-forming units of macrophage and mixed colonies when plated in methylcellulose with recombinant growth factors that stimulate both precursor cells and committed myeloid cells (SCF, IL-6, IL-3, GCSF, GMCSF; Fig. 1A). This enhanced clonogenic potential revealed by in vitro culture may have uncovered a defect that is compensated for in vivo in young mice, but appears to manifest with age.

\section{Bid-deficient myeloid precursors are resistant} to death receptor signaling

Since BID is activated downstream of death receptor signaling, we investigated the susceptibility of Bid-defi-

Table 1. Myeloid expansion in premalignant and leukemic Bid-deficient mice

\begin{tabular}{|c|c|c|c|}
\hline \multicolumn{4}{|c|}{ Wild-type and Bid-deficient mice, age 18-24 months } \\
\hline & Bid $+/+$ & Premalignant Bid -/- & Leukemic Bid -/- \\
\hline WBC $(\times 1000$ cells $/ \mathrm{ml})$ & $11.37 \pm 5.28$ & $6.04 \pm 4.11$ & $16.11 \pm 18.23$ \\
\hline Absolute Neutrophil Count & $1.48 \pm 0.54$ & $2.13 \pm 2.5$ & $11.18 \pm 15.96$ \\
\hline $\mathrm{Hb}(\mathrm{g} / \mathrm{dL})$ & $13.24 \pm 1.87$ & $11.27 \pm 2.95$ & $8.59 \pm 2.92$ \\
\hline Platelets $(<1000$ cells $/ \mathrm{ml})$ & $1951 \pm 611$ & $1361 \pm 555$ & $549 \pm 420$ \\
\hline Liver $(g)$ & $1.5 \pm 0.27$ & $1.9 \pm 0.69$ & $5.7 \pm 2.13$ \\
\hline Spleen $(\mathrm{g})$ & $0.08 \pm 0.04$ & $0.36 \pm 0.27$ & $0.59 \pm 0.44$ \\
\hline
\end{tabular}



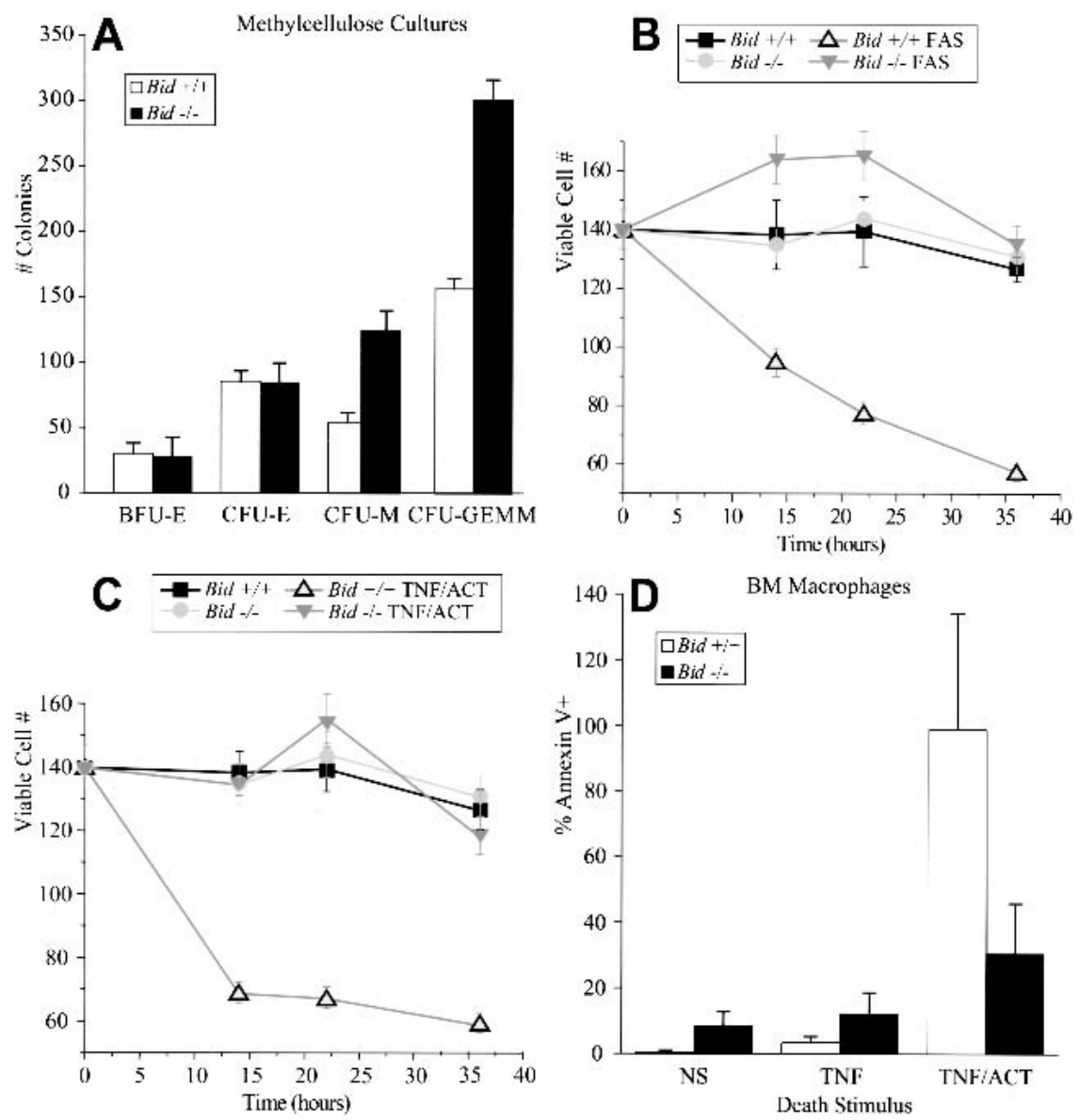

Figure 1. (A) Premalignant Bid-deficient bone marrow displays increased clonogenic potential in methylcellulose. For myeloid colonies, 10,000 cells were resuspended in Methylcult H4100 supplemented with cytokines: GCSF $(2 \mathrm{ng} / \mathrm{mL})$, GMCSF (10 ng/mL), Il3 (20 ng/mL), Il6 (4 $\mathrm{ng} / \mathrm{mL})$, Il11 (10 ng/mL), SCF (20 ng/mL). For erythroid colonies, cells were supplemented with cytokines SCF $(20 \mathrm{ng} / \mathrm{mL})$ and erythropoietin $(4 \mathrm{U} / \mathrm{mL})$. Colonies were counted on day 7. Appropriate assessment of colony morphology was verified by May Grunwald-Giemsa stained cytospins from representative colonies. $(B, C)$ $B i d$-deficient myeloid precursor cells are resistant to anti-Fas $\mathrm{Ab}$ (Jo2)- and $\mathrm{TNF} \alpha$ / actinomycin D-induced death. Lin-SCA1+ myeloid precursor cells from 8-12-wk-old mice were cultured in the presence of SCF, GCSF, and Il3. Cultures containing $80 \%-$ $90 \%$ promyelocytes and myelocytes were treated with anti-Fas $\mathrm{Ab}(\mathrm{Jo} 2, \mu \mathrm{g} / \mathrm{mL} ; B)$ or $\mathrm{TNF} \alpha+$ actinomycin $\mathrm{D}(20 \mathrm{ng} / \mathrm{mL} ; C)$, as TNF $\alpha$ alone was not effective. Viable cells were determined over a $36-\mathrm{h}$ time course by trypan blue exclusion and annexin $\mathrm{V}$ staining. (D) Bid-deficient macrophages are resistant to TNF- $\alpha$ /actinomycin D-induced death. Primary bone marrow cells from 8-12-wk-old mice were cultured for 1 wk in MCSF and IL3. Cells were treated with TNF $\alpha(10 \mathrm{ng} / \mathrm{mL})$ or TNF $\alpha+$ actinomycin D $(20 \mathrm{ng} / \mathrm{mL})$. After $72 \mathrm{~h}$, cells were stained with annexin $\mathrm{V}$ and analyzed by flow cytometry. cient myeloid precursor cells to death receptor engagement. Lin ${ }^{\text {neg }}$, Sca- $1^{\text {pos }}$ precursor cells from 8-12-wk-old mice were cultured in the presence of SCF, GCSF, and IL-3 (McLemore et al. 2001), yielding 80\%-90\% promyelocytes and myelocytes. Viability assays indicated that Bid-deficient myeloid precursors were markedly resistant to death induced by anti-Fas antibody $(\mathrm{Ab})$ and by TNF $\alpha$ (Fig. 1B,C). A small but reproducible increase in viable total cell numbers in anti-Fas-treated versus untreated Bid-/- cells leaves open the possibility of an unopposed proliferation signal, as suggested in other cell types (Kataoka et al. 2000). Resistance to TNF $\alpha$-induced apoptosis was also noted in mature Bid-deficient macrophages (Fig. 1D). Wild-type as well as Bid-deficient macrophages were resistant to anti-Fas $\mathrm{Ab}$ (data not shown), consistent with prior reports (Perlman et al. 1999).

\section{$B I D$ regulates homeostasis}

of long-term repopulating myeloid cells

We next examined the progenitor cell populations in Bid-/- animals at $12 \mathrm{wk}, 14 \mathrm{mo}$, and 16 mo. Myeloid progenitor populations are characterized by isolation of Lin-ckit+scal cells by FACS sorting, and staining for Fc $\gamma \mathrm{II} / \mathrm{III}$ and CD34. This protocol allows the separation of megakaryocyte-erythrocyte progenitors, which are Fc $\gamma \mathrm{II} / \mathrm{III}^{\text {low }}$ and CD34+; granulocyte/macrophage progenitors (GMPs), which are Fc $\gamma \mathrm{II} / \mathrm{III}^{\text {high }}$ and CD34+; and common myeloid progenitors (CMPs), which are Fc $\gamma \mathrm{II} /$ $\mathrm{III}^{\text {low }}$ and CD $34^{\text {low }}$. We found that the progenitor populations in the Bid-/- animals were not increased. Similarly, the relative number of cells marking as hematopoietic stem cells (HSCs) defined as lineage-negative (lineage = Il-7R, B220, CD19, IgM, Thy1.1, Ter119, Gr1), Sca1+, Ckit+ is equivalent in wild-type and Bid-/- animals. This contrasts with enforced overexpression of BCL-2 in which the HSC population is increased (Traver et al. 1998).

A stringent test of hematopoietic cells is to compare the competitive ability of genetically altered versus wild-type bone marrow cells to repopulate a marrow compartment that has been depleted by lethal $\gamma$-irradiation (Szilvassy et al. 1990). Similar frequencies of competitive repopulating units (CRUs) were noted for Ly5.2+marked wild-type [1:16919 (1 CRU per number transferred cells), 95\% confidence interval: 12141-23578] and Bid-deficient (1:17483, 95\% confidence interval: 1349222653) bone marrow 1 mo after reconstitution. The frequency of CRU remained similar at $4 \mathrm{mo}(\mathrm{Bid}+/+$ 1:21566; 95\% confidence interval: 15664-29692, and 
Bid-/- 1:29497; 95\% confidence interval: 22074-39418), indicating that the absolute numbers of cells capable of long-term repopulation cells do not obviously differ between the groups. However, over a 4-mo time course, the Ly5.2+-marked Bid-deficient cells comprised a significantly increasing percentage of peripheral blood, indicating a competitive advantage for Bid-/- cells (Fig. 2A). This was most prominent for CD11b+ cells, which include myeloid precursor and mature monocytic and granulocytic cells $(\mathrm{p}=0.0069 ; 4 \mathrm{mo}$; Fig. $2 \mathrm{~B})$. A trend was also noted in B220+ cells (precursor and mature B cells); however, it did not reach statistical significance ( $\mathrm{p}=0.112 ; 4$ mo; Fig. 2C). In contrast, the repopulation of $\mathrm{CD} 3+\mathrm{T}$ cells did not vary, indicating a lineage restriction for this particular role of BID, in which the different kinetics of T lymphopoiesis could be a factor (Fig. 2D). Although Bid deficiency did not alter the number of stem cells or early progenitors, defective death receptor killing as manifested in the myeloid precursors does appear to provide a competitive advantage, which is evidenced by expanded myelomonocytic cells presumably derived from long-term repopulating cells in vivo.

\section{Bid-null mice progress to CMML}

Given the disordered cellular homeostasis, we monitored a cohort of Bid-/- and Bid+/+ mice over a 2-year period. Kaplan-Meier analysis demonstrated that Bid-deficient mice display increased mortality $(\mathrm{p}=0.003$; Fig. $3 \mathrm{~A})$, increased tumor incidence (Fig. 3B; Table 2), and a shortened time to death from tumor $(\mathrm{p}=0.01)$. The most prominent malignancy of Bid-/- mice by 2 years of age was a pathology that closely resembled human CMML (53\%; $\mathrm{p}=0.002$; Table 2). The incidence of CMML increased to $73 \%$ by 27 mo of age. Moreover, Bid heterozygous mice displayed an intermediate incidence in which 4 of 12 Bid+/- mice followed developed CMML.

Necropsy of leukemic Bid-deficient mice revealed massive hepatosplenomegaly and variable lymphadenopathy (Fig. 4A; Table 1) in which the spleen was particularly enlarged (Fig. 4B). Peripheral blood displayed anemia, thrombocytopenia, and leukocytosis, with a predominance of monocytes $(-21 \%)$ and neutrophils (Fig. $5 \mathrm{~A}, \mathrm{C}$; Table 1). Bone marrow revealed a myeloproliferative disorder with predominantly mature monocytes and granulocytes in which blasts were $<15 \%$ (Fig. 5B,D). Both liver and spleen displayed a myeloid infiltrate and prominent extramedullary hematopoiesis (Fig. 5E,F). Flow cytometric analysis of cells from bone marrow and spleen of leukemic Bid-deficient mice confirmed the myeloid immunophenotype of this proliferative disorder (Fig. 6C,D). A marked increase in CD11b+Gr1+ cells was indicative of expanded immature myeloid cells and mature neutrophils, whereas increased CD11b+Gr1- cells indicated expanded monocytes. A relative decrease in the percentage of $\mathrm{T}$ cells (CD4+ and $\mathrm{CD} 8+$ ) and $\mathrm{B}$ cells (B220+) was noted in bone marrow and spleen. Neither macrophages (F4/80+) nor plasma cells (B220-, CD138+) were increased (Fig. 6C,D).

The myeloproliferation of Bid-/- mice pursues a chronic course in which mice demonstrate a myeloid expansion but little impairment for months. Eventually,
Figure 2. $(A-D)$ Bid-deficient myeloid cells display a competitive advantage in repopulating assays. Eight thousand Ly5.2+ wild-type or Bid knockout bone marrow cells along with $1.2 \times 10^{5}$ Ly5.1+ bone marrow cells (1:20 ratio) were injected intravenously into the tail vein of lethally irradiated Ly5.1+ wild-type congenic mice. Percentages of donor repopulation as assessed by percent Ly5.2+ cells $(A)$, percent Ly5.2+CD11b+ cells $(B)$, percent Ly5.2+B220+ cells $(C)$, and percent Ly5.2+CD3+ cells $(D)$ were determined by flow cytometric analysis of peripheral blood.
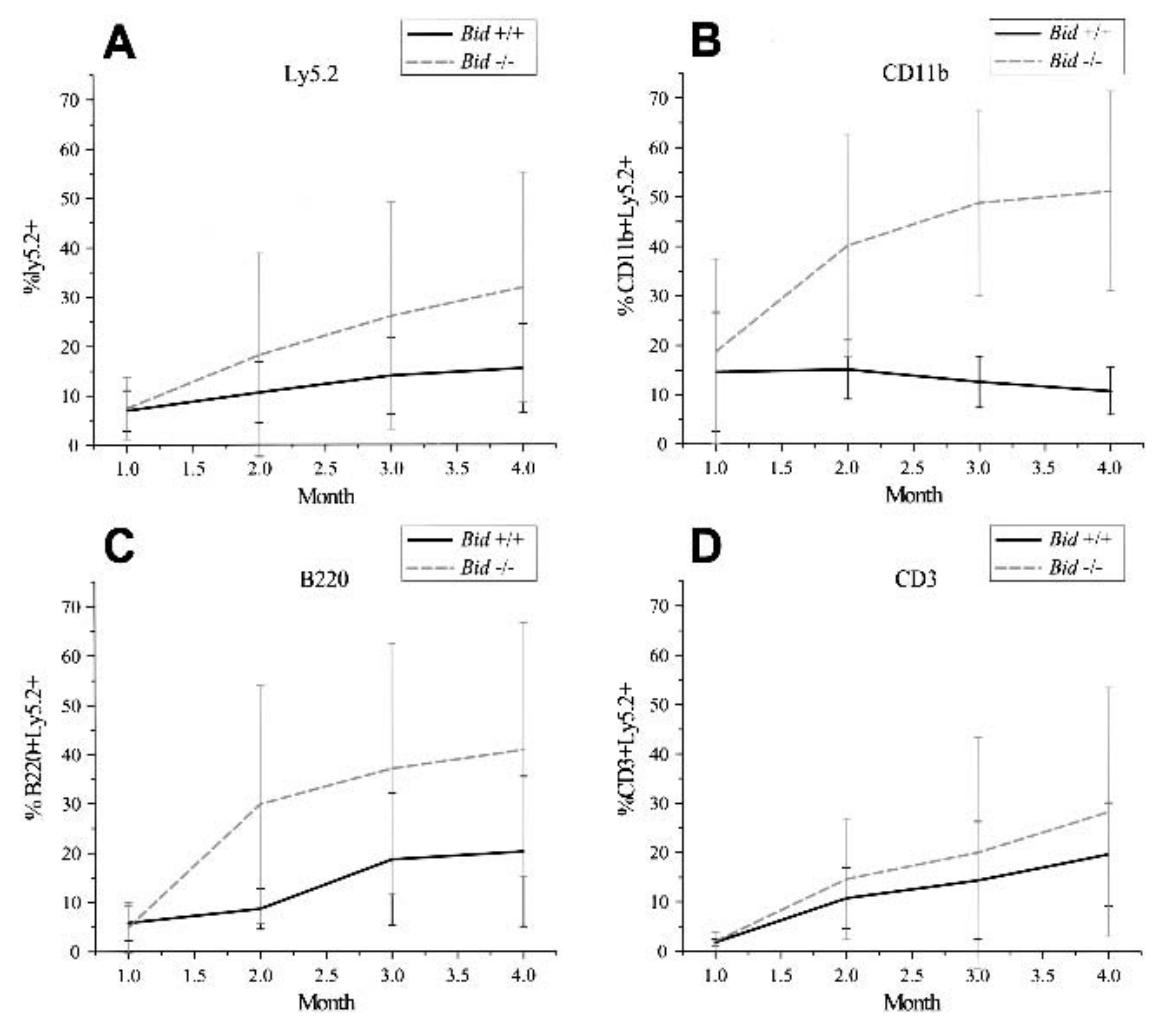
A

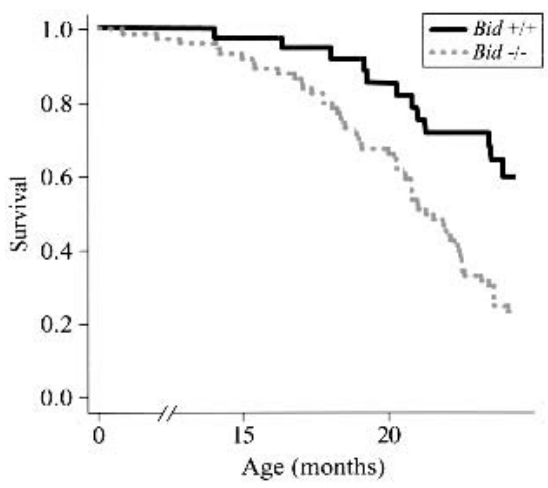

B

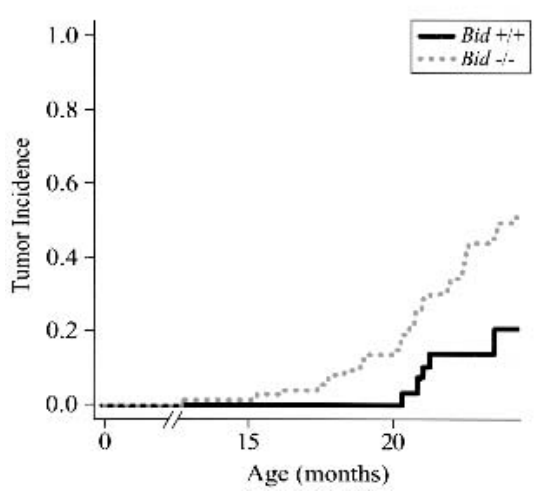

Figure 3. Bid-deficient mice display increased mortality and increased tumor incidence. $(A)$ Kaplan-Meier survival plot for 38 wild-type and 74 Bid-deficient mice monitored over 24 mo. Bid-/- mice show increased mortality $(\mathrm{p}=0.003)$, and a shortened time to death from tumor $(\mathrm{p}=0.01)$. (B) Tumor incidence. Among mice that died of tumor, the presence of CMML between the Bid-deficient and wild type was highly significant $(\mathrm{p}=0.002)$.

nearly all mice display prominent hepatosplenomegaly and subsequently progress to life-threatening complications secondary to organomegaly (Figs. $4 \mathrm{~A}, \mathrm{~B} ; 5 \mathrm{E}, \mathrm{F}$ ), tumor thrombi, or bone marrow replacement (Fig. 5B,D). This compilation of findings, including the chronic course, monocytosis, anemia, thrombocytopenia, low percentage of blast forms, myelocytosis, and extramedullary leukemic infiltrates, most closely resembles the pathology of human CMML, a heterogeneous disorder with features that vary along a spectrum from predominantly myelodysplastic to mainly myeloproliferative in nature.

\section{Bid-deficient leukemia is transplantable}

To test the malignant potential of Bid-deficient leukemic cells, we transferred three independent primary tumors (one spleen, two bone marrow) into three sets of nine syngeneic lethally irradiated mice. All recipient
Table 2. Bid-deficient mice develop a fatal myeloproliferative malignancy

\begin{tabular}{lcc}
\hline Pathology of aged wild-type and Bid-deficient animals \\
\hline & $\begin{array}{l}B i d+/+ \\
(\mathrm{n}=38)\end{array}$ & $\begin{array}{l}B i d-/- \\
(\mathrm{n}=74)\end{array}$ \\
\hline CMML & $1(2.6 \%)$ & $39(53 \%)$ \\
Macrophage tumors & $2(5.2 \%)$ & $4(5 \%)$ \\
Macrophage hyperplasia & 0 & $8(10 \%)$ \\
Lymphoma & $1(2.6 \%)$ & $4(5 \%)$ \\
Dermatitis & $5(13 \%)$ & $9(12 \%)$ \\
Angiosarcoma & $1(2.6 \%)$ & $2(2.5)$ \\
Lung cancer & $1(2.6 \%)$ & $1(1 \%)$ \\
Polyarteritis & 0 & $3(4 \%)$ \\
Hydronephosis & $1(2.6 \%)$ & $1(1 \%)$ \\
Bullous emphysema & $2(5.2 \%)$ & $1(1 \%)$ \\
Hepatoma & $24(63 \%)$ & $3(4 \%)$ \\
Normal (sacrificed at $24 \mathrm{mos})$ &
\end{tabular}

Two mice had both CMML and lymphoma.

mice developed pathology that recapitulated the phenotype of the donors, but displayed substantially decreased latency, showing evidence of tumor by day 77 (Fig. 7). Microscopic analysis revealed extensive tumor infiltrates in spleen, liver (Fig. 7A), and lung (Fig. 7B), as well as the brain of several mice, showing evidence of hemorrhagic cerebral infarcts due to tumor thrombi (Fig. 7C). Peripheral blood also displayed expanded myeloid lineage cells. The bone marrow of recipients, following transplantation of Bid-/- leukemic bone marrow, developed an expanded cell population bearing surface markers characteristic of GMPs (Fig. 6B). This provides evidence that the Bid-deficient leukemia involves a progenitor cell population.

\section{Bid-deficient leukemia demonstrates clonal chromosomal aberrations}

To assess whether the leukemic cells showed evidence of clonality, we performed spectral karyotypes (SKY) on eight tumor specimens. Six showed evidence of chromosomal abnormalities. Two tumors displayed multiple
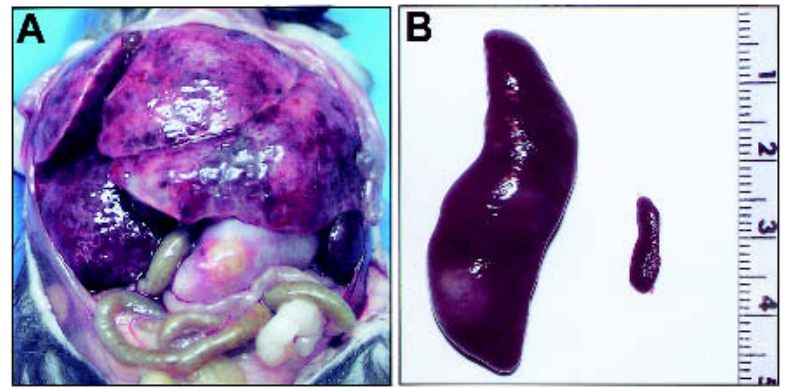

Figure 4. Massive hepatosplenomegaly typifies CMML of Biddeficient mice. (A) Bid-deficient mouse with massive hepatosplenomegaly and lymphadenopathy. (B) Spleen of same Biddeficient mouse (left) shown relative to an age-matched wildtype spleen (right). 
Zinkel et al.

Figure 5. (A) Leukemic Bid-deficient mice reveal increased mature monocytes and granulocytes. Peripheral blood May Grunwald-Giemsa stain 20x reveals leukocytosis comprised predominantly of maturing myeloid elements. (B) Bone marrow, May Grunwald-Giemsa stain 20x reveals features of a myeloproliferative disorder with marked myeloid hyperplasia consisting of predominantly mature granulocytes. (C) Peripheral blood, May Grunwald-Giemsa stain 100×. (D) Bone marrow, May Grunwald-Giemsa stain 100x. (E) Liver, hematoxylin \& eosin (H\&E) 20×. (F) Spleen, H\&E 20×. Liver and spleen reveal a myeloid infiltrate and extramedullary hematopoiesis.

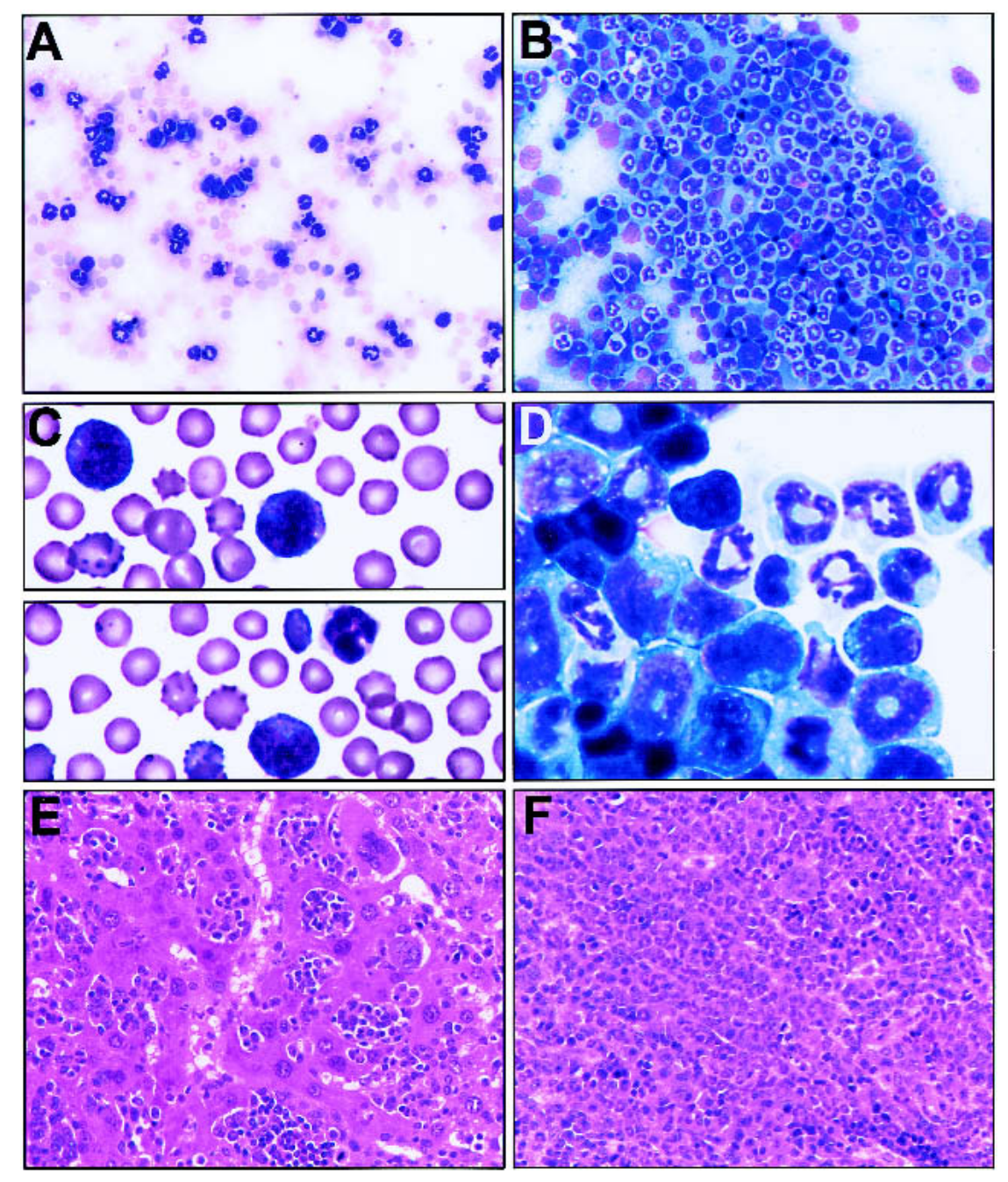

chromosomal trisomies, and the other four showed a translocation or an amplicon. All metaphase spreads from a representative leukemia displayed trisomy of chromosomes 5, 6, 15, 18, 19|, and 4/11 metaphase spreads examined contained a $\mathrm{t}(6: 11)$. These findings support a clonal/oligoclonal origin of the tumor (Fig. 8).

\section{Discussion}

\section{BID maintains myeloid homeostasis}

These studies establish that a single $\mathrm{BH} 3$-only molecule can be essential to maintain long-term cellular homeostasis within a lineage. Loss of BID leads to an accumulation of myeloid cells over time, demonstrating a critical role for this $\mathrm{BH} 3$-only molecule that amplifies death receptor signals in physiologic deaths that assure balanced cell numbers in the myeloid lineage. Consistent with this, enforced overexpression of BCL-2 in the myeloid lineage was noted to extend neutrophil survival (Lagasse and Weissman 1997). Overexpression of an antiapoptotic member rather globally blocks apoptosis through the intrinsic pathway, indicating the participa- tion of a mitochondrial pathway in myeloid homeostasis. However, this loss-of-function model indicates that developmentally appropriate levels of BID, which connects the extrinsic to the intrinsic death pathways, are specifically used to control myeloid homeostasis.

Lpr mice, which harbor a mutation in the Fas receptor, develop extramedullary myelopoiesis, which first suggested a role for Fas in the control of myeloid homeostasis (Schneider et al. 1999). An examination of cell lines suggested that certain lineages do not (Type I) and do (Type II) require a mitochondrial amplification loop to execute death signals initiated by death receptors (Scaffidi et al. 1999). Liver as a representative Type II cell did require BID to undergo apoptosis following a pathological Fas stimulus (Yin et al. 1999). However, the need for this mitochondrial amplification loop in vivo to control cellular homeostasis had not been established. For example, the liver developed normally and remained normal-sized as our unchallenged Bid-deficient mice aged. However, both mature macrophages and myeloid progenitor cells from Bid-deficient mice demonstrated profound resistance to death receptor-induced apoptosis. The myeloproliferative disorder that ensues in Bid-defi- 


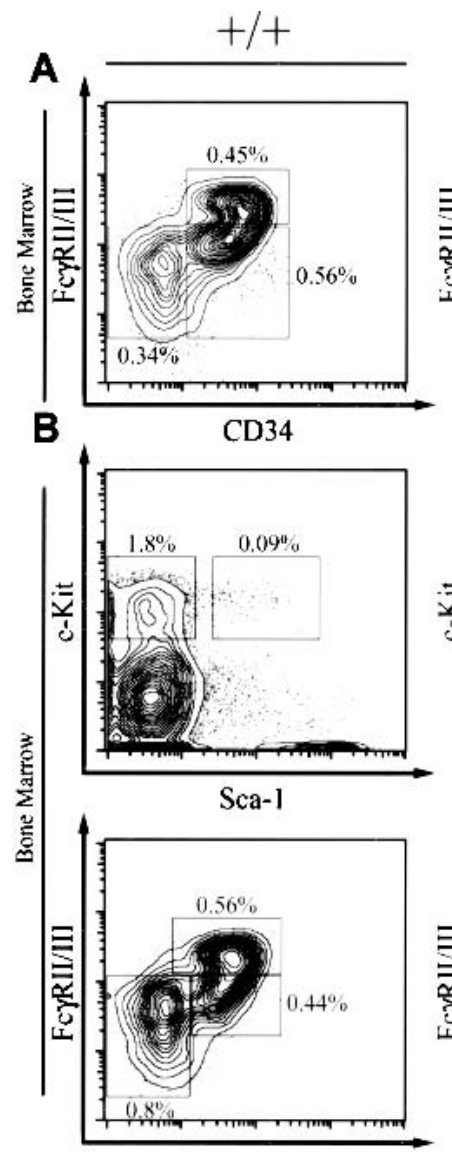

CD34

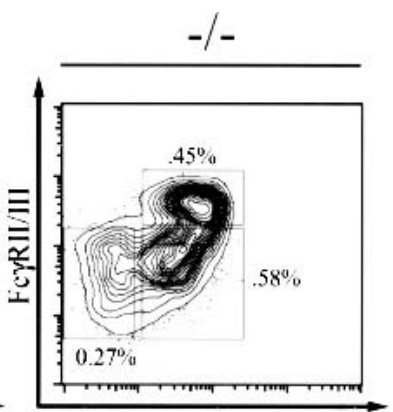

CD34

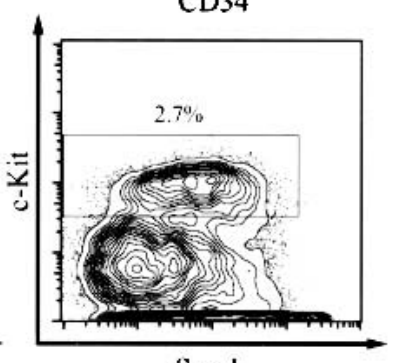

Sca-I



CD34

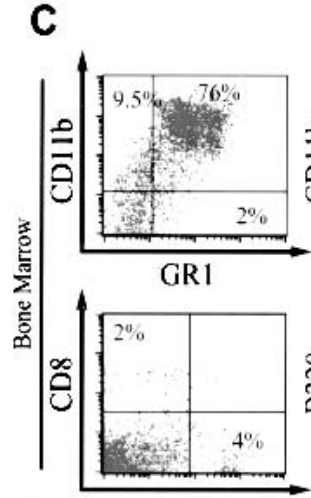

D



CD4

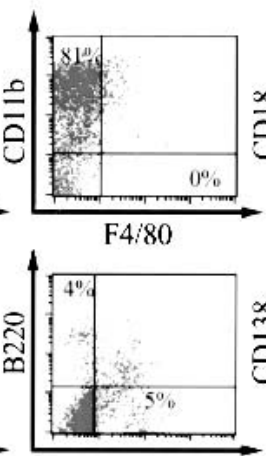

CD3

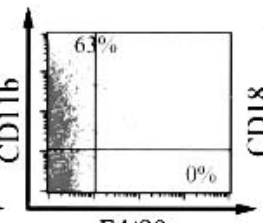

F4/80



CD3

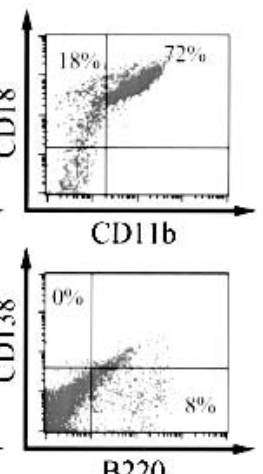

B220

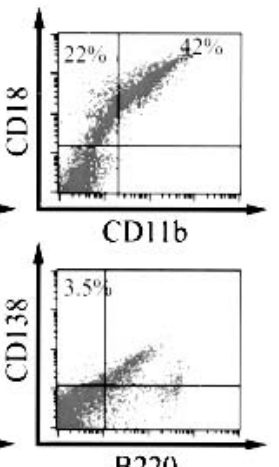

B220

Figure 6. (A) Bid-/- bone marrow displays normal numbers of progenitor cells. FACS-staining profiles of progenitor populations from littermate Bid+/+ or Bid-/- bone marrow (14-16 mo of age). The lineage (Lin) cocktail consists of: CD3, CD4, CD8, B220, CD19, Ter119, Mac-1, Gr-1. Lin ${ }^{-}$, c-kit ${ }^{+}$, Sca- $1^{-}$cells were collected by flow sorting, and stained for CD34 and Fc $\gamma \mathrm{II} / \mathrm{III}$ to delineate subpopulations of progenitor cells. HSCs were defined as $\mathrm{Lin}^{-}$, c-kit ${ }^{\text {high }}$, Sca- $1^{\text {high }}$. Myeloid-erythroid progenitors were defined as Lin ${ }^{-} \mathrm{c}-$ kit ${ }^{\text {high }} \mathrm{CD} 34^{-}$Fc $\gamma \mathrm{II} / \mathrm{III}{ }^{\mathrm{lo}}$, GMPs were defined as $\mathrm{Lin}^{-} \mathrm{c}-\mathrm{kit}^{\text {high }} \mathrm{CD} 34^{+} \mathrm{Fc} \gamma \mathrm{II} / \mathrm{III}{ }^{\text {high }}$, and CMPs were defined as $\mathrm{Lin}^{-} \mathrm{c}-\mathrm{kit}{ }^{\text {high }} \mathrm{CD} 34^{+} \mathrm{Fc} \gamma \mathrm{II} / \mathrm{IIII}{ }^{\mathrm{lo}}$. (B) Transferred Bid-/- leukemic bone marrow demonstrates an expansion of GMP. FACS-staining profiles of progenitor populations of bone marrow from a secondary transplant of leukemic Bid-/- bone marrow reveals increased lin ${ }^{\text {neg }}$, Sca ${ }^{\text {pos }}$, c-kit ${ }^{\text {pos }}$ cells consistent with expansion of GMP cells. Immunophenotype of bone marrow $(C)$ and spleen $(D)$ cells from a representative, primary leukemic Bid-deficient mouse. Flow cytometric analysis revealed an expansion of myeloid precursor cells and mature monocytes. There is a corresponding relative depletion of T cells (CD3+, CD4+, CD8+) and B cells (B220+). Plasma cells (CD138+B220-) and macrophages $(\mathrm{F} 4 / 80+)$ were not expanded. Samples were gated on live cells based on forward and side scatter profiles.

cient mice demonstrates that a BID-mediated amplification loop is critical to maintain cellular homeostasis in vivo, specifically in the myeloid lineage.

Of note is that Bid-deficient bone marrow, when transferred, demonstrates a competitive advantage in select cell lineages that persists long-term in repopulation assays in vivo. This implicates BID in regulating homeostasis of the myeloid and macrophage compartments derived from long-term repopulating cells. Broadly blocking apoptosis by overexpression of BCL-2 has been shown to result in increased HSCs by surface marker analysis, as well as in increased competitive repopulating ability (Domen et al. 2000). Our data indicate that proapoptotic BID as a singular member regulates homeostasis in the myeloid compartment at physiologic levels during normal development.

\section{$B I D$ is essential to suppress tumorigenesis}

Also of note is that BID deficiency, a proximal defect in the death receptor pathway, results in a clonal malignancy, CMML. Chronic myeloid leukemia (CML) syndromes in human patients are associated with chromosomal translocations resulting in constitutive activation of tyrosine kinases, most notably the BCR/ABL $t(9 ; 22)$ fusion in CML (for review, see Kelly and Gilliland 2002). Dysregulation of these tyrosine kinases is thought to result in a proliferative and perhaps survival advantage for cells. One model for myeloid leukemogenesis holds that abnormalities in differentiative cell fates contributed by transcription factors are complimented by proliferative signals from activated tyrosine kinases (Deguchi and Gilliland 2002). The development of CMML in the Bid- 
Zinkel et al.

Figure 7. (A) Leukemic cells from Bid-deficient animals display malignant potential. Microscopic analysis of secondary bone marrow transplant animals demonstrated aggressive tumor infiltrate in multiple organs. (A) Liver, H\&E-stained paraffin section $(20 \times)$ reveals a diffuse infiltrate of mature monocytic cells. (B) Lung, H\&Estained paraffin section $(20 \times)$ reveals tumor infiltrate filling blood vessels. $(C)$ Brain, H\&E-stained paraffin section $(20 \times)$ reveals tumor infiltrate obstructing blood vessels with associated hemorrhagic infarct. (D) May Grunwald-Giemsa stained peripheral blood $(100 \times)$ shows mature myeloid elements.


deficient mouse underscores that loss of apoptosis can be a key component of myeloproliferative disorders.

The long latency for development of CMML indicates the acquisition of secondary oncogenic events, as is characteristic of tumor progression (Land et al. 1983). Acquired secondary oncogenic events often attempt to trigger apoptosis. In this instance it is possible that such an apoptotic signal might be mediated via death receptors, as Bid deficiency could be argued to have protected the cell. This would be consistent with other models in which oncogenes such as myc induce death receptor pathways (Klefstrom et al. 2002). An additional possibility is that loss of apoptotic BID might unmask a FAS proliferative pathway (Fig. 1B), thus simulating two-hit oncogenesis. When mice overexpressing BCL-2 were crossed to $\mathrm{FAS}^{1 p r / 1 p r}$, acute myeloid leukemia resulted, suggesting a synergy between the extrinsic death receptor and intrinsic BCL-2 mitochondrial pathways. Bid deficiency may constitute a dual defect, as BID is both activated by caspase 8 and inhibited by mitochondrial
BCL-2; thus, loss of BID could reset susceptibility in both extrinsic and intrinsic pathways.

Apoptosis has been shown to play a critical role in the tumor suppressor function of p53. A recent example includes a mouse model of myc-driven lymphoma in which disruption of apoptosis driven by BCL-2 overexpression alleviated the pressure to inactivate p53 during lymphomagenesis (Schmitt et al. 2002). Despite their aggressive phenotype, apoptosis-defective lymphomas that retain intact p53 genes do not display the checkpoint defects and gross aneuploidy that are characteristic of p53 mutant tumors. The consistent chromosomal abnormalities in Bid-deficient CMML in this context is surprising and warrants future studies to determine whether BID could play an unanticipated role in regulating genomic stability.

The multidomain proapoptotic molecules BAX and BAK are used more widely than BH3-only molecules, perhaps required for all intrinsic pathway cell death (Wei et al. 2001). Although the ratio of anti/proapoptotic

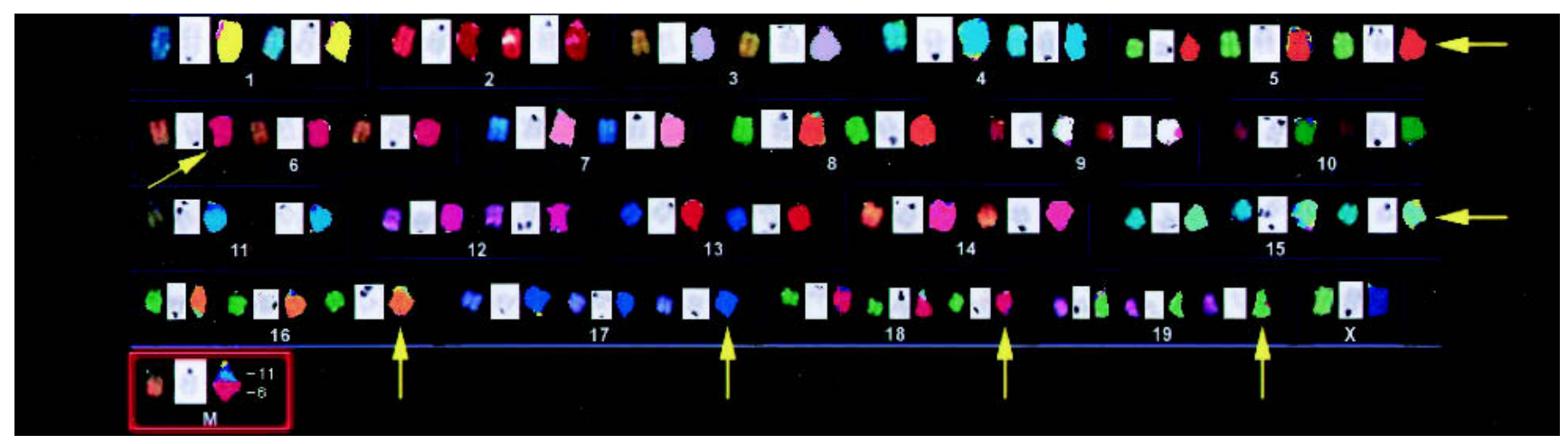

Figure 8. Bid-deficient tumors are clonal, displaying chromosomal aberrations. A representative SKY of Bid-deficient leukemia. Pseudocolored chromosomes are on the left, inverted DAPI-banded chromosomes are in the middle, and classification-colored chromosomes are on the right. Tumor displays a $\mathrm{t}(11 ; 6)$ (red box) and trisomy of multiple chromosomes (yellow arrows). 
BCL-2 members is often abnormal in cancer, the data on mutation of the multidomain death effectors BAX, BAK in human malignancies suggest that they are not frequently lost. A proof of principle does exist in that frameshift mutations in BAX have been noted in colon cancer and hematopoietic malignancies in the setting of mismatch repair defects (Rampino et al. 1997; Meijerink et al. 1998). The availability of four BAX plus BAK alleles, given their overlapping roles as downstream death effectors and their widespread coexpression, may limit their genetic participation in human cancers. Despite the signal-specific and lineage-restricted involvement of $\mathrm{BID}$, the results of the present study indicate that the loss of a single such BH3-only molecule can result in cancer. Our observations should prompt a widened survey for defects in the BH3-only genes in human cancers.

\section{Materials and methods}

\section{Precursor cultures}

Bone marrow cells were isolated from Bid-deficient mice pretreated $48 \mathrm{~h}$ with 5 Fluorouracil, $150 \mathrm{mg} / \mathrm{kg}$, by intraperitoneal injection. Myeloid precursor cells were isolated by lineage depletion, followed by positive selection of Sca-1+ cells by magnetic beads (Miltenyi). These cells were grown in the presence of SCF, Flt3, and IL-3 for $72 \mathrm{~h}$ and then induced to differentiate with G-SCF. Myeloid cells grown in this manner can be induced to differentiate in synchrony such that from day $1-3$, the cells are predominantly promyelocytes and myelocytes, and on day 5 , predominantly neutrophils (McLemore et al. 2001). Aliquots of cells were removed on days 1,3 , and 5 and treated with TNF $\alpha$ (10 ng/mL), TNF $\alpha(10 \mathrm{ng} / \mathrm{mL})+$ actinomycin $\mathrm{D}(20 \mathrm{ng} / \mathrm{mL})$, or anti-Fas $A B(J o 2,1 \mu \mathrm{g} / \mathrm{mL})$. Cell viability measured by trypan blue and annexin $\mathrm{V}$ staining (data not shown) was assessed at 12-h intervals. Cell differentiation was assessed by May Grunwald-Giemsa stains of cytospins.

\section{Methylcellulose}

For myeloid colonies, 10,000 cells were resuspended in Methylcult H4100 (StemCell Technologies) supplemented with BSA and FCS, with the following cytokines: GCSF $(2 \mathrm{ng} / \mathrm{mL})$, GMCSF (10 ng/mL), Il3 (20 ng/mL), Il6 (4 ng/mL), Il11 (10 ng/ $\mathrm{mL})$, and SCF $(20 \mathrm{ng} / \mathrm{mL})$. For erythroid colonies, 100,000 cells were resuspended in Methylcult H4100 (StemCell Technologies) supplemented with BSA and FCS, and the cytokines SCF $(20 \mathrm{ng} / \mathrm{mL})$ and erythropoietin $(4 \mathrm{U} / \mathrm{mL})$. Cells were plated in $35-\mathrm{mm}$ dishes and incubated in a humidified atmosphere at $37^{\circ} \mathrm{C}, 5 \% \mathrm{CO}_{2}$. Colonies were counted on day 7 .

\section{Experimental design of competitive reconstitution}

In brief, C57BL/6 recipients were lethally irradiated with 950 cGy given in two doses (5 h apart) from a ${ }^{137} \mathrm{Cs}$ source. A slightly modified CRU assay was used to determine the number of HSCs in bone marrow (Szilvassy et al. 1990; Rebel et al. 1994). Three doses of $8000,16,000$, or 32,000 unseparated test cells (Ly5.2+) were injected together with $1 \times 10^{5}$ unseparated adult bone marrow "helper" cells (Ly5.1+) into lethally irradiated recipients $($ Ly5.1+) Hematopoietic reconstitution was followed 4, 8, 12, and $16 \mathrm{wk}$ after the transplantation in peripheral blood. A mouse was considered to be reconstituted when, $12 \mathrm{wk}$ after the transplantation, $>1 \%$ of the peripheral blood cells are Ly5.2+ and include both myeloid and lymphoid cells, as determined by staining with CD3, CD11b, and B220. CRU frequencies for every type of bone marrow tested was calculated by analysis of the proportion of negative mice using Poisson statistics (Strijbosch et al. 1987). Results in Figure 1D are combined from two separate experiments. The reconstitution was performed on two separate occasions with three sets of 60 animals, and similar results were obtained.

A limiting dilution design was used to examine the peripheral white blood cell output from a single CRU and determine the percent of repopulation. Animals from groups in which $>37 \%$ of the mice were negative were included in the analysis. On average, such recipients would have received 1 CRU, and $<27 \%$ would have received $>2$ CRUs. In two experiments, this included seven wild-type animals and five Bid-/- animals.

\section{Data analysis}

The data from the tumor watch were analyzed with the help of the Department of Biostatistics, Dana-Farber Cancer Institute. The overall survival for the two groups of mice was calculated using the Kaplan-Meier estimate. Among the Bid-deficient mice, only three were deemed "within normal limits" (WNL); of the remaining 71, 50 died of tumors (or with tumors), and 21 died of other causes. Among the 39 wild-type mice, 29 were apparently WNL. Of the 10 wild-type animals whose deaths were not due to experimental design, 8 died of or with tumors, and 2 died from other causes. In the Bid-deficient group, median survival was $21 \mathrm{mo}$; at that time point, $79 \%$ of the wild-type mice remained alive, or had been censored for prior sacrifice in the WNL state or with dermatitis only. Tumor incidence was assessed using a competing risks model.

\section{Pathology}

Mice were dissected and weights taken of liver, lymph nodes, and spleen, organs known to be involved in myeloid malignancies of mice. Organs were fixed in Bouin's fixative or $10 \%$ formalin and embedded in paraffin for histological slides. Organ pathology was evaluated by Dr. Rod Bronson, a specialist in tumors of laboratory animals. Representative slides were reviewed by Drs. Jeff Kutok and John Aster in the hematopathology department at the Dana-Farber Cancer Institute.

\section{Spectral karyotyping}

Tumor cells from affected bone marrow and spleen were cultured for $1 \mathrm{wk}$ in MCSF to enrich for myeloid cells. Metaphase spreads were prepared by standard methods with overnight colcemid treatment (KaryoMAX colcemid solution, GIBCO-BRL). Analysis was performed on an Applied Spectral Imaging (ASI) CCD camera and interferometer attached to a Nikon Eclipse microscope equipped with $40 \times$ and $63 \times$ objective lenses. Confirmatory individual chromosome painting experiments were performed using degenerative oligonucleotide primers PCR-labeled probes generated from flow-sorted mouse chromosomes (Liyanage et al. 1996).

\section{Malignant potential}

Cell suspensions from spleen or bone marrow of affected male animals were prepared using standard methods. A range of tumor doses from 1 million to 5 million cells was injected intravenously into lethally irradiated female congenic (C57B16) mice. One million female bone marrow cells from a c57Bl6 
mouse were injected for rescue of hematopoiesis. Mice were observed with the same protocol used for the primary tumor watch. Three independent tumors were transferred into a total of 27 animals. One animal per trial was reconstituted with wildtype bone marrow as a control.

\section{Acknowledgments}

We thank D. Neuberg for statistical analysis, J. Fisher and S. Wade for mouse colony management, E. Smith for manuscript preparation, and V. Rebel for helpful discussions. This work is supported in part by NIH grant no. R01CA50239.

The publication costs of this article were defrayed in part by payment of page charges. This article must therefore be hereby marked "advertisement" in accordance with 18 USC section 1734 solely to indicate this fact.

\section{References}

Adams, J.M. and Cory, S. 1998. The Bcl-2 protein family: Arbiters of cell survival. Science 281: 1322-1326.

Bouillet, P., Metcalf, D., Huang, D.C., Tarlinton, D.M., Kay, T.W., Kontgen, F., Adams, J.M., and Strasser, A. 1999. Proapoptotic Bcl-2 relative Bim required for certain apoptotic responses, leukocyte homeostasis, and to preclude autoimmunity. Science 286: 1735-1738.

Bouillet, P., Purton, J.F., Godfrey, D.I., Zhang, L.C., Coultas, L., Puthalakath, H., Pellegrini, M., Cory, S., Adams, J.M., and Strasser, A. 2002. BH3-only Bcl-2 family member Bim is required for apoptosis of autoreactive thymocytes. Nature 415: 922-926.

Cheng, E.H., Wei, M.C., Weiler, S., Flavell, R.A., Mak, T.W., Lindsten, T., and Korsmeyer, S.J. 2001. BCL-2, BCL-X(L) sequester $\mathrm{BH} 3$ domain-only molecules preventing BAX- and BAK-mediated mitochondrial apoptosis. Mol. Cell 8: 705711.

Degenhardt, K., Chen, G., Lindsten, T., and White, E. 2002. BAX and BAK mediate p53-independent suppression of tumorigenesis. Cancer Cell 2: 193-203.

Deguchi, K. and Gilliland, D.G. 2002. Cooperativity between mutations in tyrosine kinases and in hematopoietic transcription factors in AML. Leukemia 16: 740-744.

Domen, J., Cheshier, S.H., and Weissman, I.L. 2000. The role of apoptosis in the regulation of hematopoietic stem cells: Overexpression of Bcl-2 increases both their number and repopulation potential. J. Exp. Med. 191: 253-264.

Gross, A., McDonnell, J.M., and Korsmeyer, S.J. 1999a. BCL-2 family members and the mitochondria in apoptosis. Genes \& Dev. 13: 1899-1911.

Gross, A., Yin, X.M., Wang, K., Wei, M.C., Jockel, J., Milliman, C., Erdjument-Bromage, H., Tempst, P., and Korsmeyer, S.J. $1999 \mathrm{~b}$. Caspase cleaved BID targets mitochondria and is required for cytochrome $\mathrm{c}$ release, while BCL-XL prevents this release but not tumor necrosis factor-R1/Fas death. J. Biol. Chem. 274: 1156-1163.

Hockenbery, D., Nunez, G., Milliman, C., Schreiber, R.D., and Korsmeyer, S.J. 1990. Bcl-2 is an inner mitochondrial membrane protein that blocks programmed cell death. Nature 348: 334-336.

Kataoka, T., Budd, R.C., Holler, N., Thome, M., Martinon, F., Irmler, M., Burns, K., Hahne, M., Kennedy, N., Kovacsovics, M., et al. 2000. The caspase-8 inhibitor FLIP promotes activation of NF-кB and Erk signaling pathways. Curr. Biol. 10: 640-648.

Kelly, L.M. and D.G. Gilliland. 2002. Genetics of myeloid leu- kemias. Annu. Rev. Genomics Hum. Genet. 3: 179-198.

Klefstrom, J., Verschuren, E.W., and Evan, G. 2002. c-Myc augments the apoptotic activity of cytosolic death receptor signaling proteins by engaging the mitochondrial apoptotic pathway. I. Biol. Chem. 277: 43224-43232.

Knudson, C.M., Tung, K.S., Tourtellotte, W.G., Brown, G.A., and Korsmeyer, S.J. 1995. Bax-deficient mice with lymphoid hyperplasia and male germ cell death. Science 270: 96-99.

Lagasse, E. and Weissman, I.L. 1997. Enforced expression of Bcl-2 in monocytes rescues macrophages and partially reverses osteopetrosis in op/op mice. Cell 89: 1021-1031.

Land, H., Parada, L.F., and Weinberg, R.A. 1983. Cellular oncogenes and multistep carcinogenesis. Science 222: 771-778.

Letai, A., Bassik, M., Walensky, L., Sorcinelli, M., Weiler, S., and Korsmeyer, S. 2002. Distinct BH3 domains either sensitize or activate mitochondrial apoptosis, serving as prototype cancer therapeutics. Cancer Cell 2: 183.

Li, H., Zhu, H., Xu, C.J., and Yuan, J. 1998. Cleavage of BID by caspase 8 mediates the mitochondrial damage in the Fas pathway of apoptosis. Cell 94: 491-501.

Lindsten, T., Ross, A.J., King, A., Zong, W.X., Rathmell, J.C., Shiels, H.A., Ulrich, E., Waymire, K.G., Mahar, P., Frauwirth, K., et al. 2000. The combined functions of proapoptotic Bcl-2 family members bak and bax are essential for normal development of multiple tissues. Mol. Cell 6: 13891399.

Liyanage, M., Coleman, A., du Manoir, S., Veldman, T., McCormack, S., Dickson, R.B., Barlow, C., Wynshaw-Boris, A., Janz, S., Wienberg, J., et al. 1996. Multicolour spectral karyotyping of mouse chromosomes. Nat. Genet. 14: 312-315.

Luo, X., Budihardjo, I., Zou, H., Slaughter, C., and Wang, X. 1998. Bid, a Bcl2 interacting protein, mediates cytochrome c release from mitochondria in response to activation of cell surface death receptors. Cell 94: 481-490.

McDonnell, T.J., Deane, N., Platt, F.M., Nunez, G., Jaeger, U., McKearn, J.P., and Korsmeyer, S.J. 1989. bcl-2-immunoglobulin transgenic mice demonstrate extended B cell survival and follicular lymphoproliferation. Cell 57: 79-88.

McDonnell, T.J. and Korsmeyer, S.J. 1991. Progression from lymphoid hyperplasia to high-grade malignant lymphoma in mice transgenic for the $\mathrm{t}(14 ; 18)$. Nature 349: 254-256.

McLemore, M.L., Grewal, S., Liu, F., Archambault, A., Poursine-Laurent, J., Haug, J., and Link, D.C. 2001. STAT-3 activation is required for normal G-CSF-dependent proliferation and granulocytic differentiation. Immunity 14: 193-204.

Meijerink, J.P., Mensink, E.J., Wang, K., Sedlak, T.W., Sloetjes, A.W., de Witte, T., Waksman, G., and Korsmeyer, S.J. 1998. Hematopoietic malignancies demonstrate loss-of-function mutations of BAX. Blood 91: 2991-2997.

Nakano, K. and Vousden, K.H. 2001. PUMA, a novel proapoptotic gene, is induced by p53. Mol. Cell 7: 683-694.

Perlman, H., Pagliari, L.J., Georganas, C., Mano, T., Walsh, K., and Pope, R.M. 1999. FLICE-inhibitory protein expression during macrophage differentiation confers resistance to fasmediated apoptosis. J. Exp. Med. 190: 1679-1688.

Puthalakath, H., Huang, D.C., O'Reilly, L.A., King, S.M., and Strasser, A. 1999. The proapoptotic activity of the Bcl-2 family member Bim is regulated by interaction with the dynein motor complex. Mol. Cell 3: 287-296.

Rampino, N., Yamamoto, H., Ionov, Y., Li, Y., Sawai, H., Reed, J.C., and Perucho, M. 1997. Somatic frameshift mutations in the BAX gene in colon cancers of the microsatellite mutator phenotype. Science 275: 967-969.

Rebel, V.I., Dragowska, W., Eaves, C.J., Humphries, R.K., and Lansdorp, P.M. 1994. Amplification of Sca-1+ Lin- WGA+ cells in serum-free cultures containing steel factor, interleu- 
kin-6, and erythropoietin with maintenance of cells with long-term in vivo reconstituting potential. Blood 83: 128136.

Scaffidi, C., Schmitz, I., Zha, J., Korsmeyer, S.J., Krammer, P.H., and Peter, M.E. 1999. Differential modulation of apoptosis sensitivity in CD95 type I and type II cells. J. Biol. Chem. 274: 22532-22538.

Schmitt, C.A., Fridman, J.S., Yang, M., Baranov, E., Hoffman, R.M., and Lowe, S.W. 2002. Dissecting p53 tumor suppressor functions in vivo. Cancer Cell 1: 289-298.

Schneider, E., Moreau, G., Arnould, A., Vasseur, F., Khodabaccus, N., Dy, M., and Ezine, S. 1999. Increased fetal and extramedullary hematopoiesis in Fas-deficient C57BL/6-lpr/lpr mice. Blood 94: 2613-2621.

Strijbosch, L.W., Buurman, W.A., Does, R.J., Zinken, P.H., and Groenewegen, G. 1987. Limiting dilution assays. Experimental design and statistical analysis. J. Immunol. Methods 97: 133-140.

Szilvassy, S.J., Humphries, R.K., Lansdorp, P.M., Eaves, A.C., and Eaves, C.J. 1990. Quantitative assay for totipotent reconstituting hematopoietic stem cells by a competitive repopulation strategy. Proc. Natl. Acad. Sci. 87: 8736-8740.

Traver, D., Akashi, K., Weissman, I.L., and Lagasse, E. 1998. Mice defective in two apoptosis pathways in the myeloid lineage develop acute myeloblastic leukemia. Immunity 9: 47-57.

Vaux, D.L., Cory, S., and Adams, J.M. 1988. Bcl-2 gene promotes haemopoietic cell survival and cooperates with c-myc to immortalize pre-B cells. Nature 335: 440-442.

Wang, K., Yin, X.M., Chao, D.T., Milliman, C.L., and Korsmeyer, S.J. 1996. BID: A novel BH3 domain-only death agonist. Genes \& Dev. 10: 2859-2869.

Wei, M.C., Lindsten, T., Mootha, V.K., Weiler, S., Gross, A., Ashiya, M., Thompson, C.B., and Korsmeyer, S.J. 2000. tBID, a membrane-targeted death ligand, oligomerizes BAK to release cytochrome c. Genes \& Dev. 14: 2060-2071.

Wei, M.C., Zong, W.X., Cheng, E.H., Lindsten, T., Panoutsakopoulou, V., Ross, A.J., Roth, K.A., MacGregor, G.R., Thompson, C.B., and Korsmeyer, S.J. 2001. Proapoptotic BAX and BAK: A requisite gateway to mitochondrial dysfunction and death. Science 292: 727-730.

Yin, C., Knudson, C.M., Korsmeyer, S.J., and Van Dyke, T. 1997. Bax suppresses tumorigenesis and stimulates apoptosis in vivo. Nature 385: 637-640.

Yin, X.M., Wang, K., Gross, A., Zhao, Y., Zinkel, S., Klocke, B., Roth, K.A., and Korsmeyer, S.J. 1999. Bid-deficient mice are resistant to Fas-induced hepatocellular apoptosis. Nature 400: 886-891.

Zha, J., Harada, H., Yang, E., Jockel, J., and Korsmeyer, S.J. 1996. Serine phosphorylation of death agonist BAD in response to survival factor results in binding to 14-3-3 not BCL-X(L). Cell 87: 619-628.

Zha, J., Weiler, S., Oh, K.J., Wei, M.C., and Korsmeyer, S.J. 2000. Posttranslational N-myristoylation of BID as a molecular switch for targeting mitochondria and apoptosis. Science 290: $1761-1765$.

Zong, W.X., Lindsten, T., Ross, A.J., MacGregor, G.R., and Thompson, C.B. 2001. BH3-only proteins that bind pro-survival Bcl-2 family members fail to induce apoptosis in the absence of Bax and Bak. Genes \& Dev. 15: 1481-1486. 


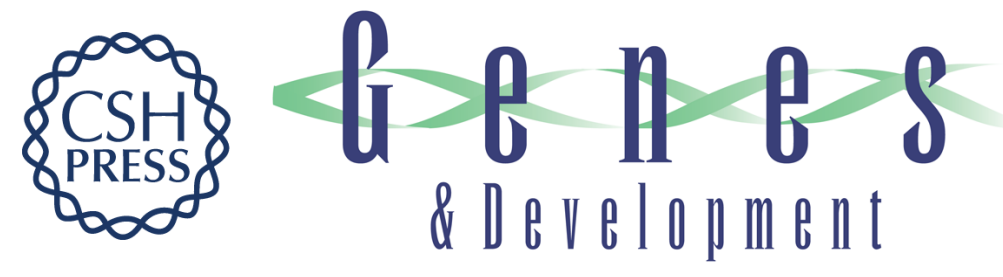

\section{Proapoptotic BID is required for myeloid homeostasis and tumor suppression}

Sandra S. Zinkel, Christy C. Ong, David O. Ferguson, et al.

Genes Dev. 2003, 17:

Access the most recent version at doi:10.1101/gad.1045603

References This article cites 45 articles, 20 of which can be accessed free at: http://genesdev.cshlp.org/content/17/2/229.full.html\#ref-list-1

License

Email Alerting

Receive free email alerts when new articles cite this article - sign up in the box at the top Service right corner of the article or click here.

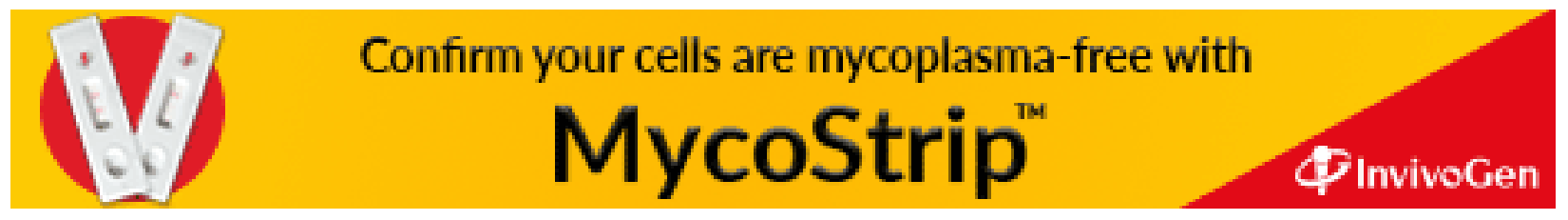

